\title{
KLF4 Gene
}

National Cancer Institute

\section{Source}

National Cancer Institute. KLF4 Gene. NCI Thesaurus. Code C73449.

This gene plays a role in gene transcription. 